Check for updates

Cite this: RSC Adv., 2018, 8, 8199

Received 10th January 2018

Accepted 16th February 2018

DOI: $10.1039 / c 8 r a 00269 j$

rsc.li/rsc-advances

\section{The effect of 3D carbon nanoadditives on lithium hydroxide monohydrate based composite materials for highly efficient low temperature thermochemical heat storage}

\author{
Shijie Li, ${ }^{\text {ab }}$ Hongyu Huang, (D) *a Jun Li, ${ }^{\star c}$ Noriyuki Kobayashi, ${ }^{c}$ Yugo Osaka, ${ }^{d}$ \\ Zhaohong He $\mathrm{H}^{\mathrm{a}}$ and Haoran Yuan ${ }^{\mathrm{a}}$
}

Lithium hydroxide monohydrate based thermochemical heat storage materials were modified with in situ formed 3D-nickel-carbon nanotubes (Ni-CNTs). The nanoscale $(5-15 \mathrm{~nm}) \mathrm{LiOH} \cdot \mathrm{H}_{2} \mathrm{O}$ particles were well dispersed in the composite formed with Ni-CNTs. These composite materials exhibited improved heat storage capacity, thermal conductivity, and hydration rate owing to hydrogen bonding between $\mathrm{H}_{2} \mathrm{O}$ and hydrophilic groups on the surface of Ni-CNTs, as concluded from combined results of in situ DRIFT spectroscopy and heat storage performance test. The introduction of 3D-carbon nanomaterials leads to a considerable decrease in the activation energy for the thermochemical reaction process. This phenomenon is probably due to Ni-CNTs providing an efficient hydrophilic reaction interface and exhibiting a surface effect on the hydration reaction. Among the thermochemical materials, Ni-CNTs$\mathrm{LiOH} \cdot \mathrm{H}_{2} \mathrm{O}-1$ showed the lowest activation energy $\left(23.3 \mathrm{~kJ} \mathrm{~mol}{ }^{-1}\right)$, the highest thermal conductivity $\left(3.78 \mathrm{~W} \mathrm{~m}^{-1} \mathrm{~K}^{-1}\right.$ ) and the highest heat storage density $\left(3935 \mathrm{~kJ} \mathrm{~kg}^{-1}\right)$, which is 5.9 times higher than that of pure lithium hydroxide after the same hydration time. The heat storage density and the thermal conductivity of Ni-CNTs- $\mathrm{LiOH} \cdot \mathrm{H}_{2} \mathrm{O}$ are much higher than 1D MWCNTs and 2D graphene oxide modified $\mathrm{LiOH} \cdot \mathrm{H}_{2} \mathrm{O}$. The selection of 3D carbon nanoadditives that formed part of the chemical heat storage materials is a very efficient way to enhance comprehensive performance of heat storage activity components.

\section{Introduction}

As an important part of clean and efficient utilization of alternative energy, the development of thermal energy storage technology has become increasingly important in recent years owing to the incremental consumption of fossil energy and the emission of greenhouse gases. ${ }^{\mathbf{1}, 2}$ These technologies are divided into three main types: sensible heat storage,,$^{3,4}$ latent heat storage, ${ }^{5,6}$ and thermochemical heat storage. ${ }^{7,8}$ All of these technologies participate in solving the supply and demand mismatch of thermal energy, and improve energy efficiency. ${ }^{9}$ Among these technologies, thermochemical heat storage, which

\footnotetext{
${ }^{a}$ Key Laboratory of Renewable Energy, Guangdong Provincial Key Laboratory of New and Renewable Energy Research and Development, Guangzhou Institute of Energy Conversion, Chinese Academy of Sciences, No. 2 Nengyuan Rd, Wushan, Tianhe District, Guangzhou 510640, P. R. China.E-mail: lisj@ms.giec.ac.cn; huanghy@ms. giec.ac.cn; hezh@ms.giec.ac.cn; yuanhr@ms.giec.ac.cn

${ }^{b}$ University of Chinese Academy of Sciences, Beijing 100049, PR China

${ }^{c}$ Nagoya University, Furo-cho, Chikusa-ku, Nagoya-shi, Aichi 464-8603, Japan. E-mail: Junli@energy.gr.jp; kobayashi@energy.gr.jp

${ }^{d}$ Kanazawa University, Kanazawa-shi, Ishikawa-ken 920-1192, Japan. E-mail: y-osaka@se.kanazawa-u.ac.jp
}

uses reversible chemical reactions to store and release thermal energy, facilitates the efficient utilization of thermal energy due to its high heat storage density. ${ }^{10}$ Based on heat storage working temperature, the thermochemical heat storage technology could be divided into two parts: high temperature heat storage and low temperature heat storage. ${ }^{9,10}$ As core components of these technologies, numerous thermochemical materials (TCMs) have been selected. For instance, metal hydroxides, metal hydrides, and metal carbonates are typically used as TCMs for high-temperature thermochemical heat storage, whereas inorganic salt hydrates and salt ammoniate are considered as promising candidates for low-temperature thermochemical heat storage due to their different decomposition temperature. ${ }^{11-16}$ For efficiently storing low-temperature thermal energy, the inorganic hydrate lithium hydroxide monohydrate $\left(\mathrm{LiOH} \cdot \mathrm{H}_{2} \mathrm{O}\right)$, which possesses high energy density $\left(1440 \mathrm{~kJ} \mathrm{~kg}^{-1}\right)$ and mild reaction process, was selected as a potential material. ${ }^{17}$ However, similar to other inorganic hydrates ${ }^{18,19}$ pure $\mathrm{LiOH} \cdot \mathrm{H}_{2} \mathrm{O}$ exhibit low hydration rate and thermal conductivity; ${ }^{15,17}$ moreover, its heat storage density decreases after hydration, thereby seriously limiting the application of the material. Hence, composite TCMs with high heat 
storage density and high thermal conductivity are of considerable synthetic value.

3D carbon nanomaterials (3D-carbon nanotube sponge and arrays $^{20,21}$ ), which exhibit large surface area, low bulk density, and chemical stability, ${ }^{22-24}$ are widely used in various fields, such as electronics ${ }^{25,26}$ and catalysis ${ }^{24,27}$ as typical carbon nanomaterials. In addition, these materials offer excellent hydrophilic property after the introduction of surface oxygen groups. However, under normal conditions, traditional one-dimensional or two-dimensional carbon nanomaterials are selected and used for latent heat thermal energy storage. ${ }^{2,28,29} 3 \mathrm{D}$ carbon nanomaterials are rarely used for thermal energy storage, ${ }^{30}$ especially thermochemical heat storage. In our previous work, $1 \mathrm{D}$ carbon nanomaterials, ${ }^{31}$ MWCNTs were used to modify $\mathrm{LiOH} \cdot \mathrm{H}_{2} \mathrm{O}$; heat storage performance was markedly enhanced, but the thermal conductivity needed improvement. Hence, 2D-carbon nanomaterial ${ }^{15,32}$ graphene oxide was selected and, which markedly improved the energy storage performance of $\mathrm{LiOH} \cdot \mathrm{H}_{2} \mathrm{O}$ and $\mathrm{Mg}(\mathrm{OH})_{2}$. Graphene oxide also positively affected thermal conductivity to a certain extent. Hydrophilic substances, such as lithium chloride (LiCl), 13X-zeolite, and NaY-zeolite, were also used to enhance the heat storage performance and obtain expected results. ${ }^{33}$ Kato et al. investigated the reaction behavior of metal-salt modified $\mathrm{Mg}(\mathrm{OH})_{2^{-}}$ based materials; during the heat storage process, LiCl and LiBr acted as catalysts and decreased the activation energy effectively and substantially improved heat storage performance. ${ }^{5,11,34}$ Moreover, the functional groups on the surface of the materials markedly affected the reaction behavior of $\mathrm{Mg}(\mathrm{OH})_{2}$. However, the relationship between heat storage density and particle size, especially when materials reached nanoscale, was not discussed. In this work, in situ DRIFT spectroscopy technology and chemical reaction kinetics test were used for an in-depth analysis of the heat storage mechanism, which has not been involved in previous research. Moreover, to simultaneously improve the performance of heat storage density, hydration rate, and thermal conductivity, we synthesized a novel TCM composite of in situ formed 3D-nickelcarbon nanotubes (Ni-CNTs) and $\mathrm{LiOH} \cdot \mathrm{H}_{2} \mathrm{O}$. Four kinds of TCMs were prepared, and the effect of 3D-carbon nanomaterials was extensively investigated. The highest heat storage density of $\mathrm{Ni}-\mathrm{CNTs}-\mathrm{LiOH} \cdot \mathrm{H}_{2} \mathrm{O}$ could reach $3935 \mathrm{~kJ} \mathrm{~kg}^{-1}$, which is 2.2 times higher than that of 1D MWCNTs modified $\mathrm{LiOH} \cdot \mathrm{H}_{2} \mathrm{O}(1804 \mathrm{~kJ}$ $\left.\mathrm{kg}^{-1}\right)$ and the thermal conductivity $\left(3.78 \mathrm{~W} \mathrm{~m}^{-1} \mathrm{~K}^{-1}\right)$ is also much higher than MWCNTs modified $\mathrm{LiOH} \cdot \mathrm{H}_{2} \mathrm{O}\left(1.75 \mathrm{~W} \mathrm{~m}^{-1} \mathrm{~K}^{-1}\right)^{31}$ The heat storage density and the thermal conductivity of Ni-CNTs modified $\mathrm{LiOH} \cdot \mathrm{H}_{2} \mathrm{O}$ are also higher than $2 \mathrm{D}$ graphene oxide modified $\mathrm{LiOH} \cdot \mathrm{H}_{2} \mathrm{O}\left(1980 \mathrm{~kJ} \mathrm{~kg}^{-1} ; 1.70 \mathrm{~W} \mathrm{~m}{ }^{-1} \mathrm{~K}^{-1}\right)$, respectively. ${ }^{15}$ It indicated that the selection of $3 \mathrm{D}$ nano carbon materials as composed part of the chemical heat storage materials is a very efficient way to enhance comprehensive performance of heat storage activity component.

\section{Experimental}

2.1. Raw materials and synthesis method of $\mathrm{LiOH} \cdot \mathrm{H}_{2} \mathrm{O}-$ based TCMs

The 3D-carbon nanotubes were synthesized by catalytic chemical vapor deposition method with $\mathrm{C}_{2} \mathrm{H}_{4}$ as carbon source and nickel foam as catalyst. ${ }^{35}$ First, nickel foam was placed in a tubular furnace, which was heated to $700{ }^{\circ} \mathrm{C}$, and filled with $\mathrm{Ar} / \mathrm{H}_{2}(300 \mathrm{~mL} / 100 \mathrm{~mL})$ mixed reducing gas for $2 \mathrm{~h}$. After reduction, $\mathrm{Ar} / \mathrm{H}_{2}$ mixed gas was replaced with $\mathrm{Ar} / \mathrm{C}_{2} \mathrm{H}_{4}(400 \mathrm{~mL} /$ $100 \mathrm{~mL}$ ), the temperature was increased to $550{ }^{\circ} \mathrm{C}$, and the system was allowed to react for $20 \mathrm{~min}$. After the temperature decreased to $25{ }^{\circ} \mathrm{C}$, the $3 \mathrm{D}$ Ni skeleton CNTs (Ni-CNTs) was obtained. Then, after being oxidized by $5 \% \mathrm{O}_{2}$ for $2 \mathrm{~h}$ at $250{ }^{\circ} \mathrm{C}$, the as-prepared 3D Ni-CNTs were composited with $\mathrm{LiOH} \cdot \mathrm{H}_{2} \mathrm{O}$ by impregnation method. First, $0.5 \mathrm{~g} \mathrm{LiOH} \cdot \mathrm{H}_{2} \mathrm{O}$ was dissolved in $1 \mathrm{~mL}$ deionized water under vigorous stirring. Subsequently, $3 \mathrm{D}$ nanocarbon were added in the $\mathrm{LiOH}$ aqueous solution at room temperature, and the mixture was stirred continuously for $4 \mathrm{~h}$. Afterward, the products were withdrawn and vacuum freeze-dried. The obtained materials with different $\mathrm{LiOH} \cdot \mathrm{H}_{2} \mathrm{O}$ content (14 wt\%, $23 \mathrm{wt} \%, 39 \mathrm{wt} \%, 100 \mathrm{wt} \%$ ) were named as $\mathrm{Ni}$ $\mathrm{CNTs}-\mathrm{LiOH} \cdot \mathrm{H}_{2} \mathrm{O}-1$, Ni-CNTs-LiOH $\cdot \mathrm{H}_{2} \mathrm{O}-2$, Ni-CNTs-LiOH $\cdot \mathrm{H}_{2}-$ $\mathrm{O}-3$, and $\mathrm{LiOH} \cdot \mathrm{H}_{2} \mathrm{O}$, respectively.

\subsection{The characterization and heat storage performance test method of $\mathrm{LiOH} \cdot \mathrm{H}_{2} \mathrm{O}$-based TCMs}

Surface topography was measured by field-emission scanning electron microscopy (SEM, S-4800, Hitachi Limited). Transmission electron micrographs (TEM) were obtained with FEI Tecnai G212 operated at $100 \mathrm{kV}$ and a JEOL JEM-2100F operated at $200 \mathrm{kV}$. X-ray diffraction (XRD) analysis was performed on a D8-advance X-ray diffractometer (Bruker, Germany) with $\mathrm{Cu}$ target $(40 \mathrm{kV}, 40 \mathrm{~mA})$. The scan step size was $0.0167^{\circ}$, and counting time was $10.160 \mathrm{~s}$. Nitrogen adsorption-desorption was measured at the boiling point of nitrogen $(77 \mathrm{~K})$ by a Quantachrome QDS-30 analyzer. BET (Brunauer-EmmettTeller) surface area and pore structure were measured by nitrogen physisorption under normal relative pressure of 0.11.0. The thermal conductivity of the sample was measured by a DRL-II thermal conductivity tester (Xiangtan Xiangyi Instrument Co., Ltd.). $\mathrm{LiOH} \cdot \mathrm{H}_{2} \mathrm{O}$, Ni-CNTs-LiOH $\cdot \mathrm{H}_{2} \mathrm{O}-1$, Ni-CNTs$\mathrm{LiOH} \cdot \mathrm{H}_{2} \mathrm{O}-2$, Ni-CNTs- $\mathrm{LiOH} \cdot \mathrm{H}_{2} \mathrm{O}-3$ were used as raw substance then, LiOH Ni-CNTs-LiOH-1, Ni-CNTs-LiOH-2, and Ni-CNTs$\mathrm{LiOH}-3$ were synthesized by decomposing $\mathrm{LiOH} \cdot \mathrm{H}_{2} \mathrm{O}$, Ni-CNTs$\mathrm{LiOH} \cdot \mathrm{H}_{2} \mathrm{O}-1, \mathrm{Ni}-\mathrm{CNTS}-\mathrm{LiOH} \cdot \mathrm{H}_{2} \mathrm{O}-2$, and Ni-CNTs-LiOH $\cdot \mathrm{H}_{2} \mathrm{O}-3$ in a horizontal tubular quartz furnace with $\mathrm{Ar}$ gas at $150{ }^{\circ} \mathrm{C}$ for $3 \mathrm{~h}$. Dehydrated products were cooled to $30^{\circ} \mathrm{C}$ in an Ar atmosphere, and water vapor at a partial pressure of $2.97 \mathrm{kPa}$ and carried by $\mathrm{N}_{2}$ flow was introduced to the tube for $60 \mathrm{~min}$ for hydration operation at $30^{\circ} \mathrm{C}$. After hydration, the endothermic heat and temperature of the samples were measured through Thermogravimetry and Differential Scanning Calorimetry (TGDSC) (STA-200, Nanjingdazhan Co., Ltd.), which was also used for measuring weight change during dehydration step. Each TGDSC measurement was repeated three times in order to ensure correctness. The activation energy of dehydration performance of all samples was calculated using Ozawa method, ${ }^{36}$ which is applicable for calculating the activation energy of thermal decomposition and dehydration reaction. By using the Ozawa method, the following equation can be obtained based on the reaction rate expression and the Arrhenius's equation: 


$$
\ln \left(\frac{\beta}{T^{2}}\right)=\ln \frac{R}{E} \frac{A}{f(\alpha)}-\frac{E}{R} \frac{1}{T}
$$

In this equation, $E$ is the activation energy $\left(\mathrm{kJ} \mathrm{mol}^{-1}\right), \beta$ is the heating rate $\left(\mathrm{K} \mathrm{s}^{-1}\right), T$ is temperature $(\mathrm{K}), R$ is the ideal gas constant $\left(\mathrm{J}(\mathrm{mol} \mathrm{K})^{-1}\right), A$ is a pre-exponential factor, $\alpha$ is the dehydration conversion, and $f(\alpha)$ is a function of dehydration conversion. During the calculation of activation energy, the dehydration conversion was maintained at $70 \%$. The heating rates were $3 \mathrm{~K} \mathrm{~min}^{-1}, 7 \mathrm{~K} \mathrm{~min}^{-1}$ and $10 \mathrm{~K} \mathrm{~min}{ }^{-1}$, and the activation energy was obtained from the slope $(-E / R)$ of this equation.

\section{Results and discussion}

\subsection{Microstructure characterization of $\mathrm{LiOH} \cdot \mathrm{H}_{2} \mathrm{O}$-based TCMs}

Fig. 1 shows the XRD patterns of $\mathrm{LiOH} \cdot \mathrm{H}_{2} \mathrm{O}$, Ni-CNTs$\mathrm{LiOH} \cdot \mathrm{H}_{2} \mathrm{O}-1$, Ni-CNTs-LiOH $\cdot \mathrm{H}_{2} \mathrm{O}-2$, and Ni-CNTs-LiOH $\cdot \mathrm{H}_{2} \mathrm{O}-3$ samples. As shown in Fig. 1, the diffraction peaks at around $30^{\circ}$, $32.19^{\circ}, 33.64^{\circ}, 34.84^{\circ}, 37.07^{\circ}, 38.83^{\circ}, 40.06^{\circ}, 41.61^{\circ}, 43.49^{\circ}$, $49.37^{\circ}, 51.36^{\circ}, 52.47^{\circ}, 55.15^{\circ}, 55.70^{\circ}, 56.92^{\circ}, 62.15^{\circ}, 63.13^{\circ}$, $64.55^{\circ}, 65.47^{\circ}, 66.22^{\circ}, 68.35^{\circ}$ and $71.34^{\circ}$, respectively, were attributed to $\mathrm{LiOH} \cdot \mathrm{H}_{2} \mathrm{O}$, whereas the diffraction peaks at around $25^{\circ}$ were attributed to graphitic carbon. ${ }^{37}$ Meanwhile, the diffraction peaks at around $45^{\circ}, 52^{\circ}$, and $77^{\circ}$ could be assigned to metal nickel. It could be clearly seen that the diffraction peaks of $\mathrm{LiOH} \cdot \mathrm{H}_{2} \mathrm{O}$ were sharp and strong in the $\mathrm{LiOH} \cdot \mathrm{H}_{2} \mathrm{O}$ sample, but the diffraction peaks of $\mathrm{LiOH} \cdot \mathrm{H}_{2} \mathrm{O}$ became weaker and more diffused when $3 \mathrm{D}$ carbon nanomaterial Ni-CNTs were added. Hence, the composites of NiCNTs and $\mathrm{LiOH} \cdot \mathrm{H}_{2} \mathrm{O}$ were successfully synthesized, and the addition of Ni-CNTs resulted in the extensive dispersion of $\mathrm{LiOH} \cdot \mathrm{H}_{2} \mathrm{O}$ particles in the composite materials.

Fig. 2a-d provide the SEM images of $\mathrm{LiOH} \cdot \mathrm{H}_{2} \mathrm{O}$, Ni-CNTs$\mathrm{LiOH} \cdot \mathrm{H}_{2} \mathrm{O}-1$, Ni-CNTs-LiOH $\cdot \mathrm{H}_{2} \mathrm{O}-2$, and Ni-CNTs-LiOH $\cdot \mathrm{H}_{2} \mathrm{O}-$

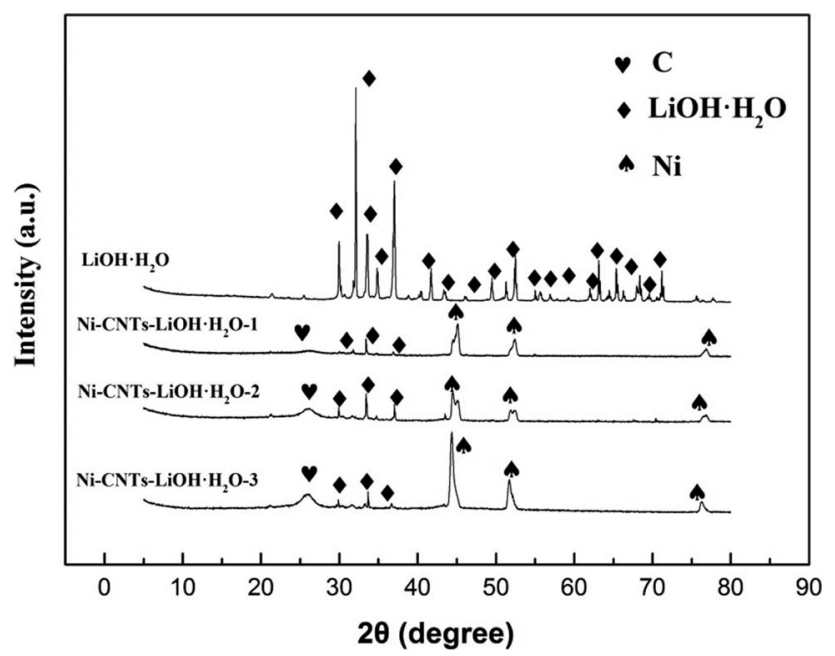

Fig. 1 XRD patterns of $\mathrm{LiOH} \cdot \mathrm{H}_{2} \mathrm{O}$, Ni-CNTs-LiOH$\cdot \mathrm{H}_{2} \mathrm{O}-1, \mathrm{Ni}-\mathrm{CNTs}-$ $\mathrm{LiOH} \cdot \mathrm{H}_{2} \mathrm{O}-2, \mathrm{Ni}-\mathrm{CNTs}-\mathrm{LiOH} \cdot \mathrm{H}_{2} \mathrm{O}-3$.

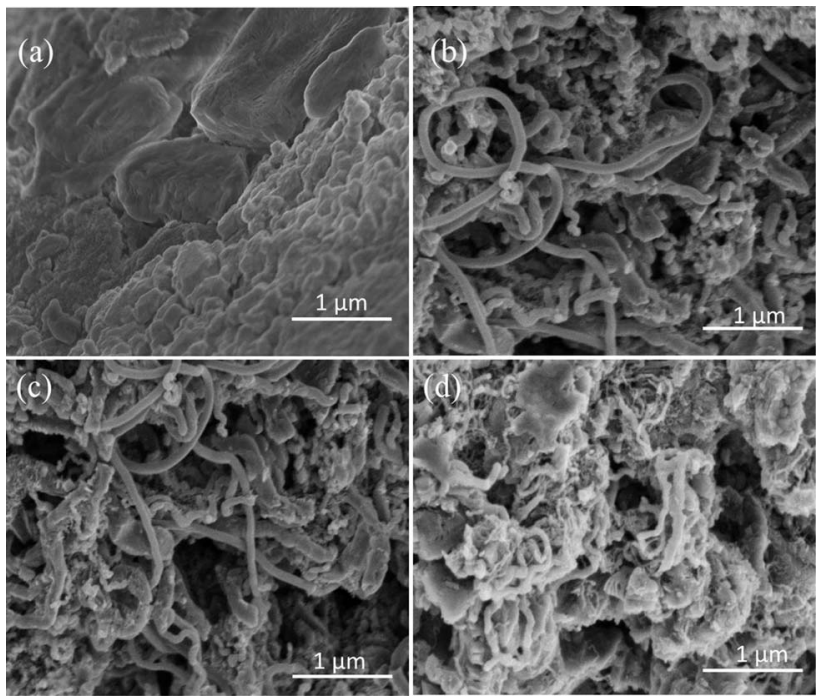

Fig. 2 SEM images of (a) $\mathrm{LiOH} \cdot \mathrm{H}_{2} \mathrm{O}$, (b) Ni-CNTs-LiOH $\cdot \mathrm{H}_{2} \mathrm{O}-1$, (c) $\mathrm{Ni}-$ CNTs- $\mathrm{LiOH} \cdot \mathrm{H}_{2} \mathrm{O}-2$ and (d) Ni-CNTs- $\mathrm{LiOH} \cdot \mathrm{H}_{2} \mathrm{O}-3$.

3, respectively. As shown in Fig. 2a, before the addition of 3Dcarbon nanoadditives, the bulk $\mathrm{LiOH} \cdot \mathrm{H}_{2} \mathrm{O}$ was aggregated with a large diameter ( $300 \mathrm{~nm}$ to $2 \mu \mathrm{m}$ ). After the modification of Ni-CNTs, no obvious change was observed in the regular structure for Ni-CNTs-LiOH $\cdot \mathrm{H}_{2} \mathrm{O}-1$ (Fig. 2b) and Ni-CNTs$\mathrm{LiOH} \cdot \mathrm{H}_{2} \mathrm{O}-2$ (Fig. 2c). This finding indicates that the intervention of $\mathrm{LiOH} \cdot \mathrm{H}_{2} \mathrm{O}$ did not lead to structural deterioration at a mass ratio $<23 \%$ and that $\mathrm{LiOH} \cdot \mathrm{H}_{2} \mathrm{O}$ was highly dispersed in the composite materials. This result agrees well with the XRD result. When the content of $\mathrm{LiOH} \cdot \mathrm{H}_{2} \mathrm{O}$ reached $39 \%$ (Ni-CNTs$\mathrm{LiOH} \cdot \mathrm{H}_{2} \mathrm{O}-3$ ), several $\mathrm{LiOH} \cdot \mathrm{H}_{2} \mathrm{O}$ particles could be seen on the surface of Ni-CNTs (Fig. 2d).

Fig. 3 shows the TEM images of Ni-CNTs-LiOH $\cdot \mathrm{H}_{2} \mathrm{O}$ with different contents of $\mathrm{LiOH} \cdot \mathrm{H}_{2} \mathrm{O}$. In Fig. $3, \mathrm{LiOH} \cdot \mathrm{H}_{2} \mathrm{O}$ nanoparticles with a diameter around $5 \mathrm{~nm}$ were successfully dispersed on Ni-CNTs (Fig. 3b) with clear particle structure. $\mathrm{LiOH} \cdot \mathrm{H}_{2} \mathrm{O}$ particle size showed a growth trend with increasing $\mathrm{LiOH} \cdot \mathrm{H}_{2} \mathrm{O}$ content in Ni-CNTs-LiOH $\cdot \mathrm{H}_{2} \mathrm{O}$ composite materials (Fig. 3d and f). When $\mathrm{LiOH} \cdot \mathrm{H}_{2} \mathrm{O}$ content reached $39 \%$ (Fig. 3f), the $\mathrm{LiOH} \cdot \mathrm{H}_{2} \mathrm{O}$ nanoparticle size could increase to $15 \mathrm{~nm}$, which is a bit bigger than the other two composite materials. Pure $\mathrm{LiOH} \cdot \mathrm{H}_{2} \mathrm{O}$ (Fig. 2a) existed in the form of stacked flakes and showed the largest particle size ( $300 \mathrm{~nm}$ to $2 \mu \mathrm{m}$ ). The addition of Ni-CNTs can effectively induce nanoscale $\mathrm{LiOH} \cdot \mathrm{H}_{2} \mathrm{O}$ dispersion, and the resulting particle size is markedly smaller than that of pure $\mathrm{LiOH} \cdot \mathrm{H}_{2} \mathrm{O}$. During the synthesis of Ni-CNTs$\mathrm{LiOH} \cdot \mathrm{H}_{2} \mathrm{O}$ composite materials, intermolecular interaction, such as hydrogen bonding, may exist between Ni-CNTs and $\mathrm{LiOH} \cdot \mathrm{H}_{2} \mathrm{O}$ owing to the presence of oxygen-containing functional groups, such as hydroxyl, carbonyl, and carboxyl groups ${ }^{38-40}$ on the surface of Ni-CNTs. Therefore, proper additives supplied hydrogen bonding could show good ability for retarding the aggregation of $\mathrm{LiOH} \cdot \mathrm{H}_{2} \mathrm{O}$. The porosity structures of $\mathrm{LiOH} \cdot \mathrm{H}_{2} \mathrm{O}$ were also measured by nitrogen adsorptiondesorption. The BET specific surface area, pore volume, and average pore size are shown in Table 1 . Ni-CNTs-LiOH $\cdot \mathrm{H}_{2} \mathrm{O}$ 


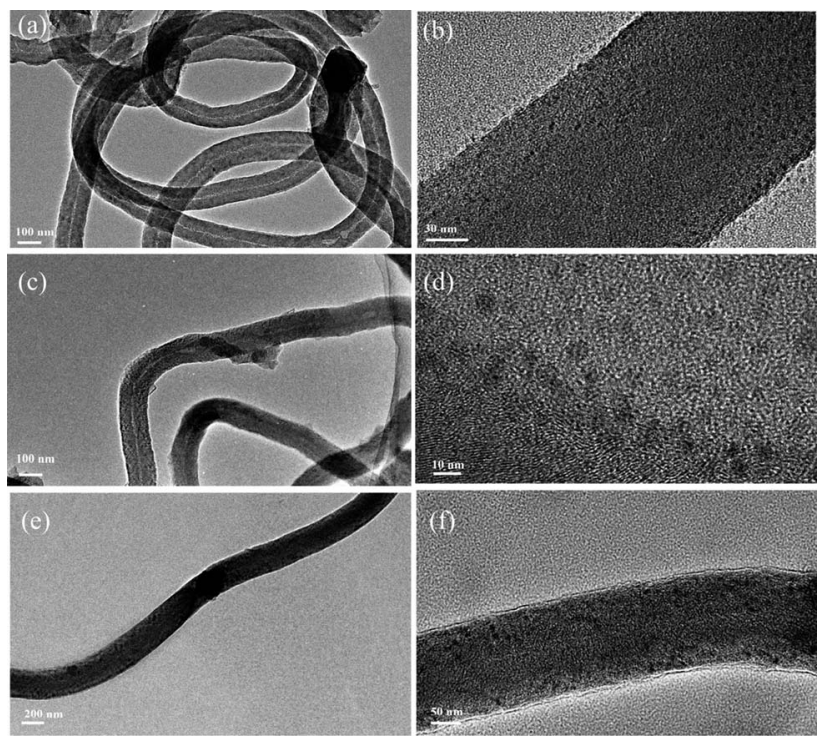

Fig. 3 TEM images of (a) Ni-CNTs- $\mathrm{LiOH} \cdot \mathrm{H}_{2} \mathrm{O}-1$, (c) Ni-CNTs$\mathrm{LiOH} \cdot \mathrm{H}_{2} \mathrm{O}-2$, (e) Ni-CNTs-LiOH$\cdot \mathrm{H}_{2} \mathrm{O}-3$, and HRTEM images of (b) Ni$\mathrm{CNTs}-\mathrm{LiOH} \cdot \mathrm{H}_{2} \mathrm{O}-1$ (d) Ni-CNTs-LiOH$\cdot \mathrm{H}_{2} \mathrm{O}-2$ and (f) Ni-CNTs$\mathrm{LiOH} \cdot \mathrm{H}_{2} \mathrm{O}-3$.

samples show different textures. Owing to the addition of $\mathrm{Ni}$ CNTs with different mass ratio, Ni-CNTs- $\mathrm{LiOH} \cdot \mathrm{H}_{2} \mathrm{O}$ shows a larger specific surface area than pure $\mathrm{LiOH} \cdot \mathrm{H}_{2} \mathrm{O}\left(15 \mathrm{~m}^{2} \mathrm{~g}^{-1}\right)$. According to SEM and TEM characterization results, high specific surface area is an important cause of the nanoscale dispersion of $\mathrm{LiOH} \cdot \mathrm{H}_{2} \mathrm{O}$ particles.

\subsection{Heat storage performance test on $\mathrm{LiOH} \cdot \mathrm{H}_{2} \mathrm{O}$-based TCMs}

The heat storage performance test of pure $\mathrm{LiOH} \cdot \mathrm{H}_{2} \mathrm{O}$, Ni-CNTs$\mathrm{LiOH} \cdot \mathrm{H}_{2} \mathrm{O}-1$, Ni-CNTs-LiOH $\cdot \mathrm{H}_{2} \mathrm{O}-2$ and Ni-CNTs-LiOH $\cdot \mathrm{H}_{2} \mathrm{O}-3$ were carried out and shown in Fig. 4. The $Y$ axis is the amount of heating per unit time and mass $\left(\mathrm{W} \mathrm{g}^{-1}\right)$, and the $X$ axis is temperature. The area of the curve is proportional to the change of enthalpy, as for heat storage materials it stands for the heat storage density. The pure $\mathrm{LiOH} \cdot \mathrm{H}_{2} \mathrm{O}$ heat storage density was only approximately $661 \mathrm{~kJ} \mathrm{~kg}^{-1}$ due to the slow reaction rate of $\mathrm{LiOH}$ and water vapor. In the hydration reaction, only about $42 \%$ of $\mathrm{LiOH}$ can be converted to $\mathrm{LiOH} \cdot \mathrm{H}_{2} \mathrm{O}$ after $1 \mathrm{~h}$ of hydration, as calculated by approximately $18 \%$ mass loss of $\mathrm{H}_{2} \mathrm{O}$ shown in Fig. $4 \mathrm{a}$. By contrast Fig. $4 \mathrm{~b}$ shows the DSC

Table 1 Texture parameters of carbon nanoadditives modified composed thermochemical materials and pure $\mathrm{LiOH} \cdot \mathrm{H}_{2} \mathrm{O}$

\begin{tabular}{llll}
\hline Samples & $\begin{array}{l}\text { Surface area } \\
\left(\mathrm{m}^{2} \mathrm{~g}^{-1}\right)\end{array}$ & $\begin{array}{l}\text { Pore volume } \\
\left(\mathrm{mL} \mathrm{g}^{-1}\right)\end{array}$ & $\begin{array}{l}\text { Average pore } \\
\text { size }(\mathrm{nm})\end{array}$ \\
\hline $\mathrm{Ni}-\mathrm{CNTs}$ & 146 & 0.30 & 8.17 \\
$\mathrm{Ni}-\mathrm{CNTs}-\mathrm{LiOH} \cdot \mathrm{H}_{2} \mathrm{O}-1$ & 119 & 0.20 & 6.79 \\
$\mathrm{Ni}-\mathrm{CNTs}-\mathrm{LiOH} \cdot \mathrm{H}_{2} \mathrm{O}-2$ & 99 & 0.11 & 6.76 \\
$\mathrm{Ni}-\mathrm{CNTs}-\mathrm{LiOH} \cdot \mathrm{H}_{2} \mathrm{O}-3$ & 62 & 0.14 & 5.62 \\
Pure LiOH $\cdot \mathrm{H}_{2} \mathrm{O}$ & 15 & 0.06 & 1.75
\end{tabular}

curve of 3D-carbon nanomaterial modified $\mathrm{LiOH} \cdot \mathrm{H}_{2} \mathrm{O}$. After $1 \mathrm{~h}$ of hydration of the Ni-CNTs- $\mathrm{LiOH} \cdot \mathrm{H}_{2} \mathrm{O}$ composite, $\mathrm{LiOH}$ was fully hydrated to $\mathrm{LiOH} \cdot \mathrm{H}_{2} \mathrm{O}$, and the heat storage density of $\mathrm{Ni}$ CNTs- $\mathrm{LiOH} \cdot \mathrm{H}_{2} \mathrm{O}-1$ normalized by $\mathrm{LiOH} \cdot \mathrm{H}_{2} \mathrm{O}$ content can reach $3935 \mathrm{~kJ} \mathrm{~kg}^{-1}$. High heat storage densities of $3505 \mathrm{~kJ} \mathrm{~kg}^{-1}$ and $2782 \mathrm{~kJ} \mathrm{~kg}^{-1}$ were observed in $\mathrm{LiOH} \cdot \mathrm{H}_{2} \mathrm{O}$ contained in $\mathrm{Ni}$ $\mathrm{CNTs}-\mathrm{LiOH} \cdot \mathrm{H}_{2} \mathrm{O}-2$ (Fig. $4 \mathrm{c}$ ) and Ni-CNTs-LiOH $\cdot \mathrm{H}_{2} \mathrm{O}-3$ (Fig. 4d), respectively. Therefore, compared with pure $\mathrm{LiOH}$ and with the same duration of the hydration reaction $\mathrm{LiOH}$, and $\mathrm{H}_{2} \mathrm{O}$ molecule can be fully converted to $\mathrm{LiOH} \cdot \mathrm{H}_{2} \mathrm{O}$ owing to the introduction of Ni-CNTs, the hydration reaction rate of $\mathrm{Ni}$ $\mathrm{CNTs}-\mathrm{LiOH} \cdot \mathrm{H}_{2} \mathrm{O}$ was substantially improved. On the one hand, owing to the formation of hydrophilic functional groups on the surface of Ni-CNTs during preparation, $\mathrm{H}_{2} \mathrm{O}$ adsorption became easier and provided a completely different reaction interface between $\mathrm{LiOH}$ and water molecules. On the other hand, Ni$\mathrm{CNTS}-\mathrm{LiOH} \cdot \mathrm{H}_{2} \mathrm{O}$ showed ultrahigh heat storage density exceeding that of pure $\mathrm{LiOH} \cdot \mathrm{H}_{2} \mathrm{O}$ owing to the existence of hydrophilic functional groups ${ }^{\mathbf{4 1}}$ and increased specific surface area, which markedly enhanced the dispersion of $\mathrm{LiOH} \cdot \mathrm{H}_{2} \mathrm{O}$ nanoparticles and the contact surface area with water molecules. The low specific surface area of pure $\mathrm{LiOH} \cdot \mathrm{H}_{2} \mathrm{O}$ may exert a negative effect on heat storage density. When the particle size reached nanoscale, the amount of surface atoms evidently increases; moreover, the crystalline field and binding energy of internal atoms were notably different from those of surface atoms, which possessed numerous dangling bonds owing to the lack of adjacent atoms. Hence, the unsaturated bonds in atoms show that nanoparticles present enhanced thermodynamic property. ${ }^{42,43}$ Meanwhile, due to increased number of surface atoms and the existence of hydrophilic functional groups, more $\mathrm{H}_{2} \mathrm{O}$ and $\mathrm{LiOH}$ can react, and therefore, heat storage performance can be improved. Furthermore, according to SEM and TEM characterization results, the heat storage density of $\mathrm{Ni}$ $\mathrm{CNTs}-\mathrm{LiOH} \cdot \mathrm{H}_{2} \mathrm{O}$ was higher than that of $\mathrm{LiOH} \cdot \mathrm{H}_{2} \mathrm{O}$ possible because of the smaller particle size of $\mathrm{LiOH} \cdot \mathrm{H}_{2} \mathrm{O}(5-15 \mathrm{~nm})$ in $\mathrm{Ni}-\mathrm{CNTs}-\mathrm{LiOH} \cdot \mathrm{H}_{2} \mathrm{O}$ than that in pure $\mathrm{LiOH} \cdot \mathrm{H}_{2} \mathrm{O}(300 \mathrm{~nm}$ to 2 $\mu \mathrm{m})$. Thus, small-sized nanoparticles can notably contribute to the enhancement of heat storage density for composite materials; as the particle size expands, the heat storage density of $\mathrm{LiOH} \cdot \mathrm{H}_{2} \mathrm{O}$ decreases. Furthermore, after the addition of NiCNTs to $\mathrm{LiOH} \cdot \mathrm{H}_{2} \mathrm{O}$, the thermal conductivity of composite materials evidently increased and exceeded that of pure $\mathrm{LiOH} \cdot \mathrm{H}_{2} \mathrm{O}$ (Fig. 5) owing to the high thermal conductivity of NiCNTs. The highest thermal conductivity of Ni-CNTs- $\mathrm{LiOH} \cdot \mathrm{H}_{2} \mathrm{O}$ can reach $3.78 \mathrm{~W} \mathrm{~m}^{-1} \mathrm{~K}^{-1}$, which is 2.2 times higher than that of pure $\mathrm{LiOH} \cdot \mathrm{H}_{2} \mathrm{O}$.

In situ DRIFT test was conducted to investigate the effect of hydrophilic functional groups of 3D-carbon nanotubes on the hydration/dehydration reaction of $\mathrm{LiOH} \cdot \mathrm{H}_{2} \mathrm{O}$. Raw materials $\mathrm{LiOH} \cdot \mathrm{H}_{2} \mathrm{O}$ and the Ni-CNTs- $\mathrm{LiOH} \cdot \mathrm{H}_{2} \mathrm{O}$ composite were exposed to a flow of $\mathrm{N}_{2}\left(300 \mathrm{~mL} \mathrm{~min}{ }^{-1}\right)$ at $150{ }^{\circ} \mathrm{C}$ to decompose for $24 \mathrm{~h}$. Then, the as-prepared samples LiOH and Ni-CNTs$\mathrm{LiOH}$ were placed in the in situ reactor of an FT-IR spectrometer. The reactor was vacuumed and purged using a He flow. The in situ DRIFT test started with the hydration reaction of $\mathrm{LiOH}$ and $\mathrm{H}_{2} \mathrm{O}$ and finished with dehydration reaction of $\mathrm{LiOH} \cdot \mathrm{H}_{2} \mathrm{O}$. 

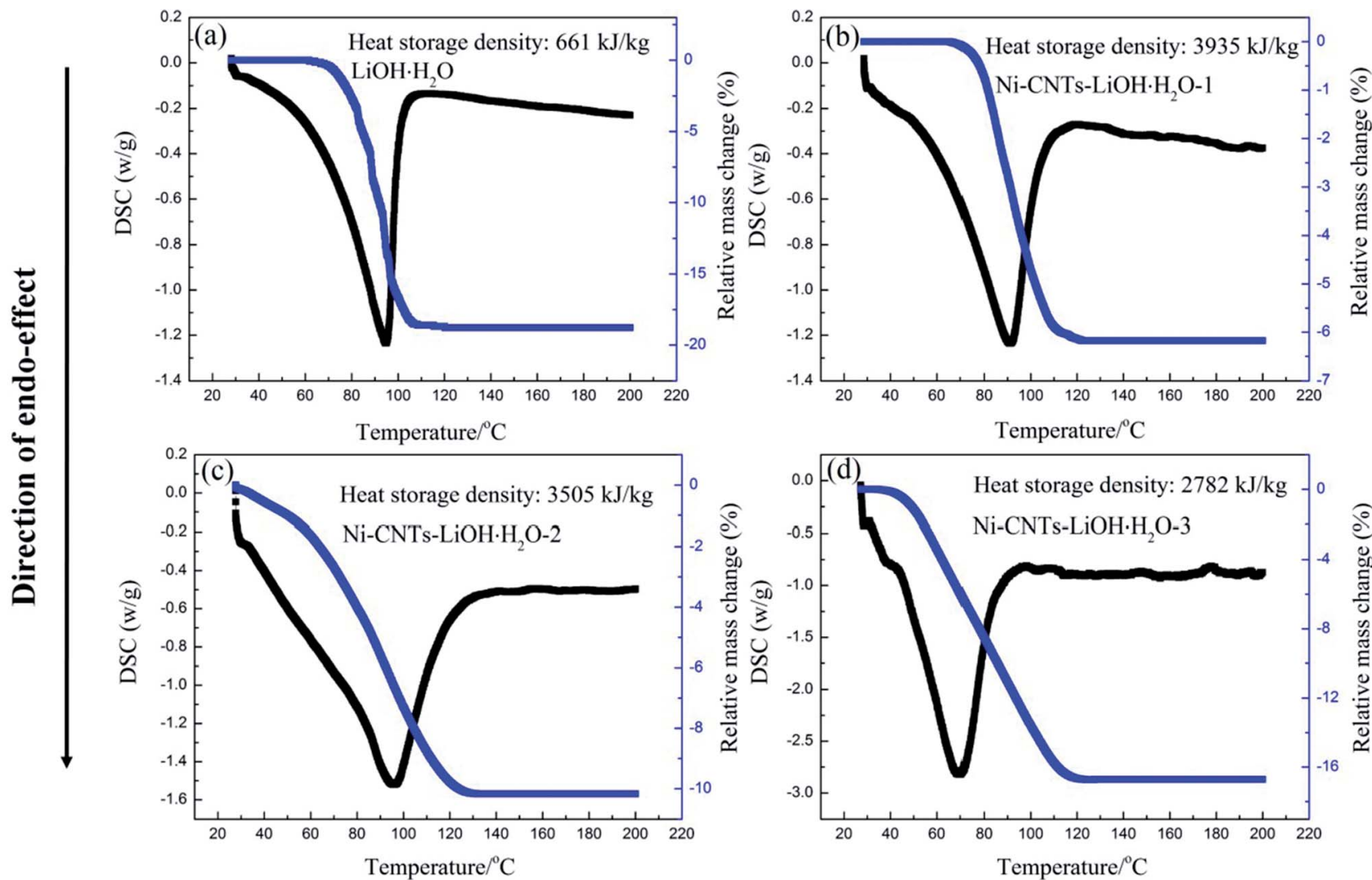

Fig. 4 TG-DSC curves of as-synthesized samples: (a) pure LiOH after $1 \mathrm{~h}$ hydration, (b) Ni-CNTs-LiOH-1 after $1 \mathrm{~h}$ hydration, (c) Ni-CNTs-LiOH2 after $1 \mathrm{~h}$ hydration, and (d) Ni-CNTs-LiOH-3 after $1 \mathrm{~h}$ hydration.

Fig. 6a shows the in situ DRIFT spectroscopy of the hydration reaction of $\mathrm{LiOH}$ and $\mathrm{H}_{2} \mathrm{O}$. The bands in the range of 3800$2200 \mathrm{~cm}^{-1}$ are always assigned to the stretching vibrations of structural $\mathrm{OH}$ groups and physical adsorbed $\mathrm{H}_{2} \mathrm{O}$ molecules. ${ }^{44}$ In the spectra, the peak at around $3679 \mathrm{~cm}^{-1}$ and $1573 \mathrm{~cm}^{-1}$ could be attributed to the stretching vibrations $\left(\nu_{\mathrm{OH}}\right)$ and bending vibrations $\left(\beta_{\mathrm{OH}}\right)$ of the structure water in $\mathrm{LiOH} \cdot \mathrm{H}_{2} \mathrm{O}$, respectively. ${ }^{45}$ Besides, broad peaks in the $2842-3423 \mathrm{~cm}^{-1}$ range were centered at around $3235 \mathrm{~cm}^{-1}$. This peak $\left(3235 \mathrm{~cm}^{-1}\right)$ and another peak at the lower band $\left(1644 \mathrm{~cm}^{-1}\right)$ were the $\nu_{\mathrm{OH}}$ and $\beta_{\mathrm{OH}}$ of $\mathrm{OH}$, respectively, in the physical adsorbed $\mathrm{H}_{2} \mathrm{O}^{44,46}$ In Fig. 6a it could be also observed that when the hydration reaction was ready for start, the weak peaks, which stand for $\mathrm{OH}$ in structure $\mathrm{H}_{2} \mathrm{O}$ and physical adsorbed $\mathrm{H}_{2} \mathrm{O}$ molecules have been existed. This finding may be due to the reaction of $\mathrm{LiOH}$ and residual physical adsorbed $\mathrm{H}_{2} \mathrm{O}$ on the surface of LiOH. With prolonged hydration reaction, the peak intensities of structural $\mathrm{OH}\left(3679 \mathrm{~cm}^{-1}\right.$ and $\left.1573 \mathrm{~cm}^{-1}\right)$ markedly increased at $15 \mathrm{~min}$ hydration. These peaks slowly increased during $15 \mathrm{~min}$ to $120 \mathrm{~min}$ hydration reaction, indicating the continuous reaction of $\mathrm{LiOH}$ and water steam and the decrease in hydration reaction rate. During this reaction, no obvious change could be observed for the peak intensities of $\mathrm{OH}\left(3235 \mathrm{~cm}^{-1}\right.$ and $1644 \mathrm{~cm}^{-1}$ ) in physical adsorbed $\mathrm{H}_{2} \mathrm{O}$ because of the steady water steam flow in the in situ reactor. After the hydration reaction, the reactor was vacuumed and purged using a dry He flow, then $\mathrm{LiOH} \cdot \mathrm{H}_{2} \mathrm{O}$ was heated at a rate of $0.5{ }^{\circ} \mathrm{C} \mathrm{s}^{-1}$ under the control of temperature-programmed technology.
Fig. 6b shows the in situ DRIFT spectroscopy of dehydration reaction of LiOH $\cdot \mathrm{H}_{2} \mathrm{O}$ obtained from $1 \mathrm{~h}$ hydration of LiOH. When $\mathrm{LiOH} \cdot \mathrm{H}_{2} \mathrm{O}$ was heated to $60{ }^{\circ} \mathrm{C}$, the peak intensities of $\mathrm{OH}$ in structural $\mathrm{H}_{2} \mathrm{O}\left(3679 \mathrm{~cm}^{-1}\right.$ and $\left.1573 \mathrm{~cm}^{-1}\right)$ started to decrease. When the temperature exceeded $70{ }^{\circ} \mathrm{C}$, the trend became more evident. Meanwhile, the peaks of $\mathrm{OH}\left(3235 \mathrm{~cm}^{-1}\right.$ and $1644 \mathrm{~cm}^{-1}$ ) in physical adsorbed $\mathrm{H}_{2} \mathrm{O}$ appeared and increased from $60^{\circ} \mathrm{C}$ to $80^{\circ} \mathrm{C}$, indicating the form of free water. The intensity of the peaks gradually decreased owing to easy

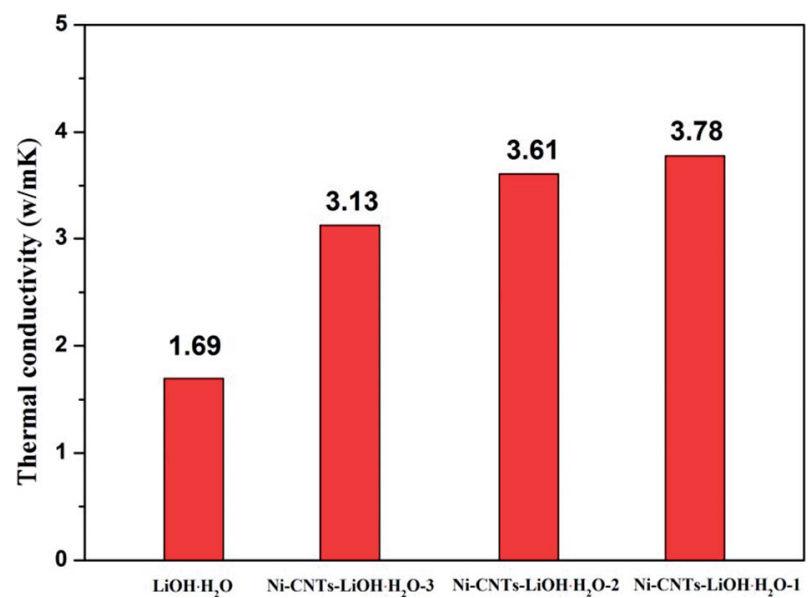

Fig. 5 Thermal conductivity of $\mathrm{LiOH} \cdot \mathrm{H}_{2} \mathrm{O}$, Ni-CNTs-LiOH$\cdot \mathrm{H}_{2} \mathrm{O}-1$, $\mathrm{Ni}-\mathrm{CNTS}-\mathrm{LiOH} \cdot \mathrm{H}_{2} \mathrm{O}-2$ and Ni-CNTs$-\mathrm{LiOH} \cdot \mathrm{H}_{2} \mathrm{O}-3$. 

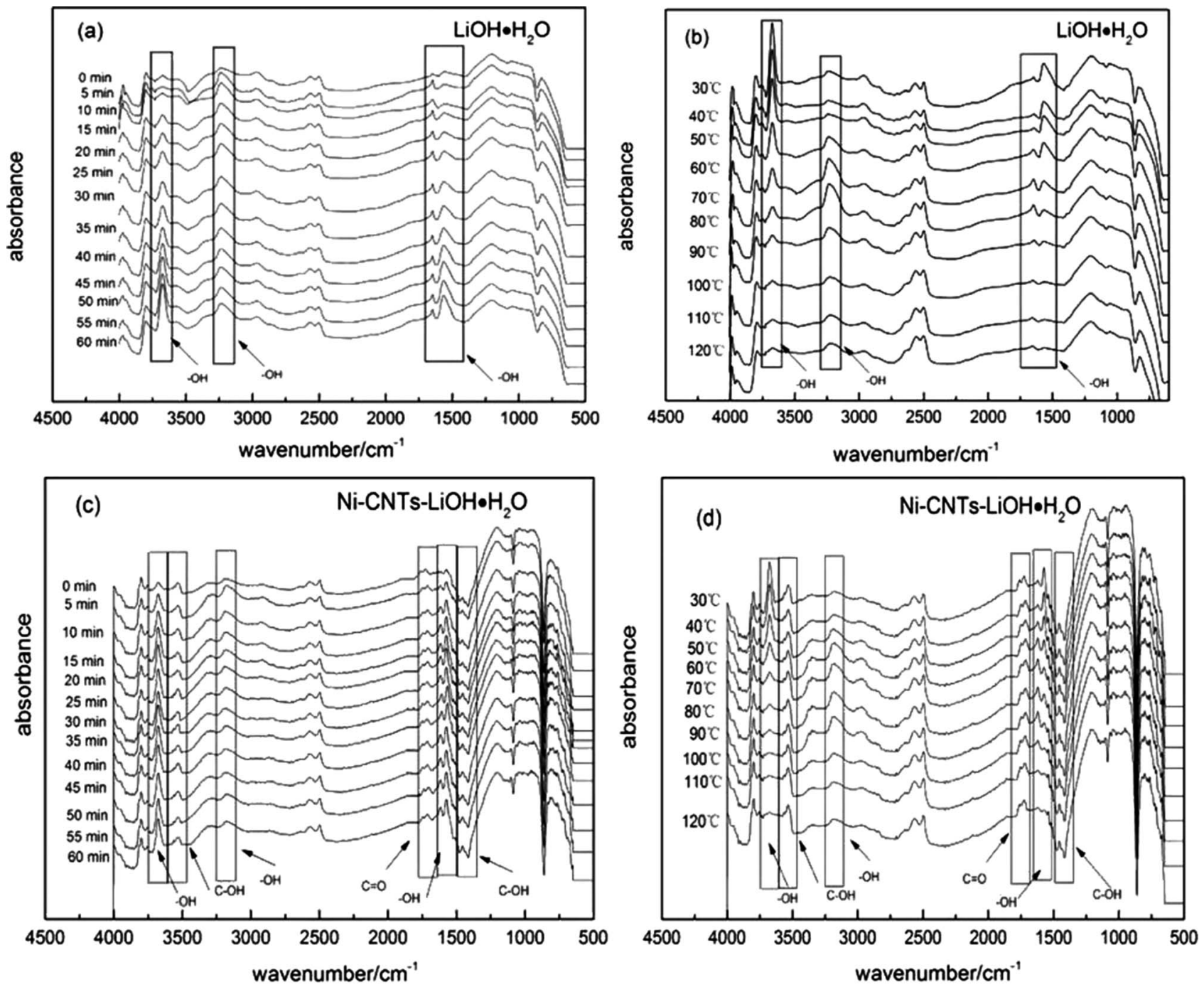

Fig. 6 (a) The in situ DRIFT spectroscopy of the hydration reaction of $\mathrm{LiOH}$; (b) the in situ DRIFT spectroscopy of dehydration reaction of $\mathrm{LiOH} \cdot \mathrm{H}_{2} \mathrm{O}$; (c) the in situ DRIFT spectroscopy of hydration reaction of Ni-CNTs-LiOH; (d) the in situ DRIFT spectroscopy of dehydration reaction of $\mathrm{Ni}-\mathrm{CNTs}-\mathrm{LiOH} \cdot \mathrm{H}_{2} \mathrm{O}$.

desorption and blowing away of physical adsorbed water at elevated temperature.

Fig. 6c shows the in situ DRIFT spectroscopy of hydration reaction of Ni-CNTs-LiOH and $\mathrm{H}_{2} \mathrm{O}$. During hydration reaction, the peak intensities of $\mathrm{OH}$ in structure $\mathrm{H}_{2} \mathrm{O}\left(3679 \mathrm{~cm}^{-1}\right.$ and $1573 \mathrm{~cm}^{-1}$ ) showed a marked increase with 5 min hydration because of the existing hydrophilic groups, such as $\mathrm{C}-\mathrm{OH}$ and $\mathrm{C}=\mathrm{O}$, on the surface of $3 \mathrm{D}$-carbon nanotubes. After $20 \mathrm{~min}$, the peaks were virtually unchanged, which indicating that the hydration reaction rate of $\mathrm{LiOH}$ and water steam was enhanced, exceeding that of pure $\mathrm{LiOH}$. The peak intensities of $\mathrm{OH}$ (3181 $\mathrm{cm}^{-1}$ and $1625 \mathrm{~cm}^{-1}$ ) in physical adsorbed $\mathrm{H}_{2} \mathrm{O}$ did not notably change. The band at around $3520 \mathrm{~cm}^{-1}$ can be assigned to stretching vibrations, whereas the band at around $1400 \mathrm{~cm}^{-1}$ was attributed to the bending vibrations of $\mathrm{C}-\mathrm{OH} .{ }^{44}$ The band at $1720 \mathrm{~cm}^{-1}$ was assigned to $\mathrm{C}=\mathrm{O}$ groups. When the water steam flowed into the reactor, the wavenumber of $\mathrm{C}=\mathrm{O}$ groups shifted from $1720 \mathrm{~cm}^{-1}$ to $1710 \mathrm{~cm}^{-1}$ because of the formation of hydrogen bonding ${ }^{2}$ between $\mathrm{C}=\mathrm{O}$ groups and adsorbed $\mathrm{H}_{2} \mathrm{O}$.
Owing to the effect of hydrogen bonding, the adsorption of $\mathrm{H}_{2} \mathrm{O}$ on the surface of Ni-CNTs-LiOH was considerably enhanced, facilitating an easier and more rapid reaction of $\mathrm{H}_{2} \mathrm{O}$ and $\mathrm{LiOH}$ than before.

Fig. 6d presented the in situ DRIFT spectroscopy of dehydration reaction of Ni-CNTs-LiOH $\cdot \mathrm{H}_{2} \mathrm{O}$. When Ni-CNTs$\mathrm{LiOH} \cdot \mathrm{H}_{2} \mathrm{O}$ was heated to $50{ }^{\circ} \mathrm{C}$, the peak intensities of $\mathrm{OH}$ in structural $\mathrm{H}_{2} \mathrm{O}\left(3679 \mathrm{~cm}^{-1}\right.$ and $\left.1573 \mathrm{~cm}^{-1}\right)$ started to decrease; beyond $60^{\circ} \mathrm{C}, \mathrm{LiOH} \cdot \mathrm{H}_{2} \mathrm{O}$ was continuously dehydrated until the structure of $\mathrm{H}_{2} \mathrm{O}$ was fully lost. Meanwhile, the peaks of $\mathrm{OH}$ $\left(3181 \mathrm{~cm}^{-1}\right.$ and $1625 \mathrm{~cm}^{-1}$ ) in physical adsorbed $\mathrm{H}_{2} \mathrm{O}$ appeared, increased from $50{ }^{\circ} \mathrm{C}$ to $90{ }^{\circ} \mathrm{C}$, and eventually decreased; this trend was ascribed to the easy removal of $\mathrm{H}_{2} \mathrm{O}$ at elevated temperature. The formed water could also produce hydrogen bonding with $\mathrm{C}=\mathrm{O}$ groups $\left(1720 \mathrm{~cm}^{-1}\right)$ on the surface of $\mathrm{Ni}$ CNTs, thereby causing a shift of the $\mathrm{C}=\mathrm{O}$ band to a lower position $\left(1710 \mathrm{~cm}^{-1}\right)$. During the dehydration reaction from $30{ }^{\circ} \mathrm{C}$ to $120{ }^{\circ} \mathrm{C}$, the intensities of $\mathrm{C}=\mathrm{O}$ and $\mathrm{C}-\mathrm{OH}\left(3520 \mathrm{~cm}^{-1}\right.$ and $1400 \mathrm{~cm}^{-1}$ ) peaks showed no obviously change, indicating 

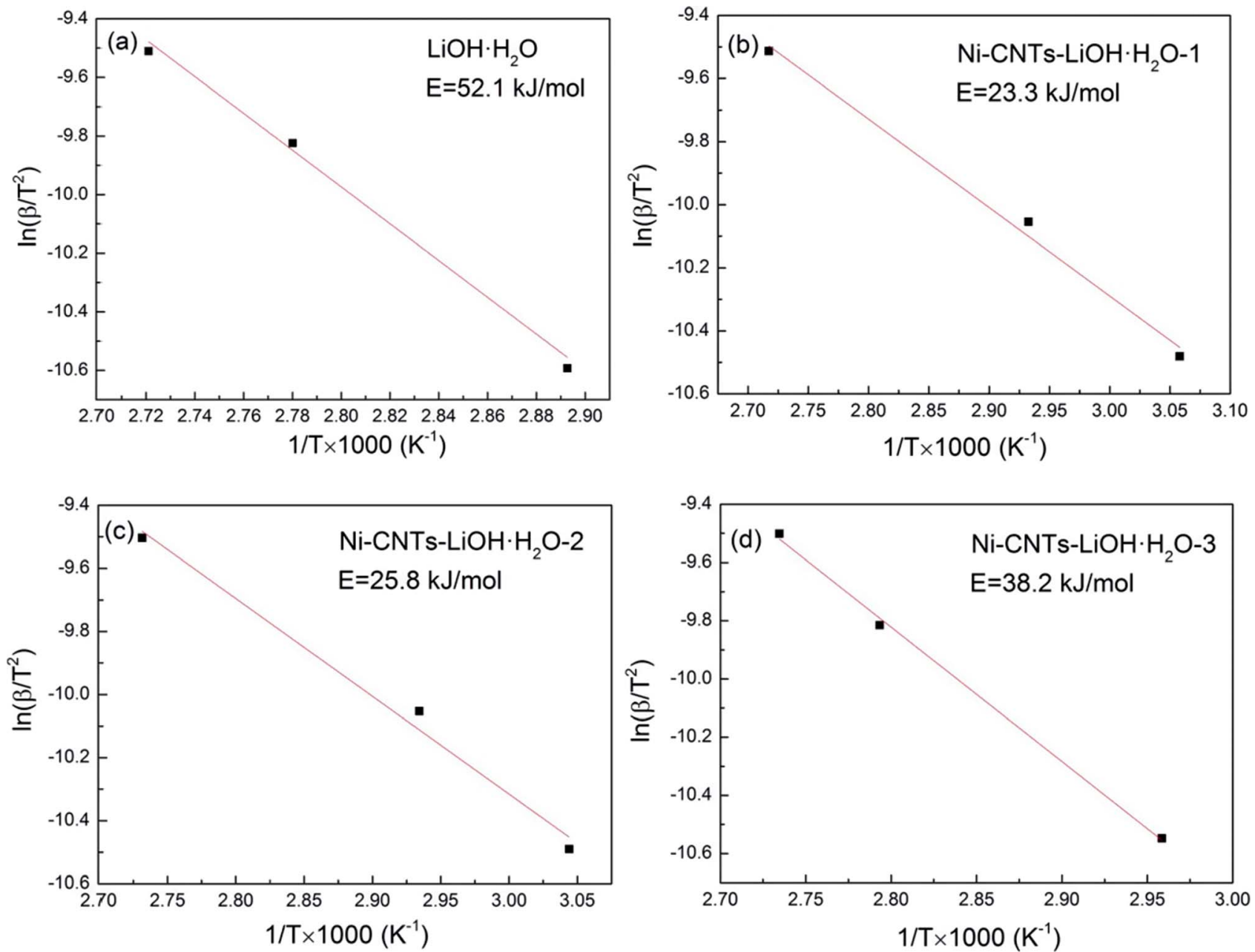

Fig. 7 The activation energy of dehydration reaction of (a) $\mathrm{LiOH} \cdot \mathrm{H}_{2} \mathrm{O}$, (b) $\mathrm{Ni}-\mathrm{CNTs}-\mathrm{LiOH} \cdot \mathrm{H}_{2} \mathrm{O}-1$, (c) $\mathrm{Ni}-\mathrm{CNTs}-\mathrm{LiOH} \cdot \mathrm{H}_{2} \mathrm{O}-2$, (d) $\mathrm{Ni}-\mathrm{CNTs}-$ $\mathrm{LiOH} \cdot \mathrm{H}_{2} \mathrm{O}-3$.

that the physical-chemical property of Ni-CNTs is steady within the total dehydration temperature range. The dehydration temperature of Ni-CNTs- $\mathrm{LiOH} \cdot \mathrm{H}_{2} \mathrm{O}$ was approximately $10{ }^{\circ} \mathrm{C}$ lower than that of pure $\mathrm{LiOH} \cdot \mathrm{H}_{2} \mathrm{O}$; this finding is in good agreement with the results of the TG-DSC test.

As shown in Fig. 7, the activation energies of the dehydration reaction of (a) $\mathrm{LiOH} \cdot \mathrm{H}_{2} \mathrm{O}$, (b) Ni-CNTs- $\mathrm{LiOH} \cdot \mathrm{H}_{2} \mathrm{O}-1$, (c) NiCNTs- $\mathrm{LiOH} \cdot \mathrm{H}_{2} \mathrm{O}-2$, and (d) Ni-CNTs- $\mathrm{LiOH} \cdot \mathrm{H}_{2} \mathrm{O}-3$ as obtained using the Ozawa method are 52.1, 23.3, 25.8, and $38.2 \mathrm{~kJ} \mathrm{~mol}^{-1}$, respectively. ${ }^{36}$ The activation energies of composite TCMs were markedly lower than that of pure $\mathrm{LiOH} \cdot \mathrm{H}_{2} \mathrm{O}$ due to the surface effect of nano- $\mathrm{LiOH} \cdot \mathrm{H}_{2} \mathrm{O}$ composite TCMs. The specific surface area or surface-to-volume ratio, which changes with particle size, depends on activation energy. ${ }^{47}$ By combining the SEM, TEM, and BET characterization results, it could be found that as the Ni-CNT content increased, the specific surface area of the composite TCMs also increased, whereas the particle size of $\mathrm{LiOH} \cdot \mathrm{H}_{2} \mathrm{O}$ decreased. The activation energy of $\mathrm{LiOH} \cdot \mathrm{H}_{2} \mathrm{O}$ dehydration reaction in composite TCMs showed similar trend to the particle size variation of $\mathrm{LiOH} \cdot \mathrm{H}_{2} \mathrm{O}$. This trend can be attributed to diminished particle size, leading to increased surface-to-volume ratio and molar surface energy of nanoparticles, which mainly result in decreased activation energy. ${ }^{48,49}$ In summary, the addition of 3D-carbon nanomaterial Ni-CNTs can not only enhance water absorption at the LiOH particle surface but also decrease activation energy. Owing to the addition of Ni-CNTs, $\mathrm{LiOH} \cdot \mathrm{H}_{2} \mathrm{O}$ are dehydrated more easily, and the reaction mechanism of composited TCMs may deviate from that of pure $\mathrm{LiOH} \cdot \mathrm{H}_{2} \mathrm{O}$ because of the surface effect of 3D Ni-CNTs-LiOH $\cdot \mathrm{H}_{2} \mathrm{O}$ nanocomposite materials during the thermochemical reaction process.

\section{Conclusions}

For investigating the effects of in situ formed 3D-carbon nanoadditives (Ni-CNTs) on the thermal performance of lowtemperature $\mathrm{LiOH} \cdot \mathrm{H}_{2} \mathrm{O}$-based composites as thermochemical heat storage materials, four kinds of $\mathrm{LiOH} \cdot \mathrm{H}_{2} \mathrm{O}$-based composite TCMs were successfully constructed and characterized. Owing to the addition of 3D-carbon nanoadditives, the nanoscale $(5-15 \mathrm{~nm}) \mathrm{LiOH} \cdot \mathrm{H}_{2} \mathrm{O}$ particles were well dispersed in the composite with Ni-CNTs. The heat storage capacity and thermal conductivity of the composite materials were markedly improved. Meanwhile, the hydration rate was enhanced due to 
the hydrogen bonding formed between $\mathrm{H}_{2} \mathrm{O}$ and hydrophilic groups on the surface of Ni-CNTs, as shown by the combined results of in situ DRIFT spectroscopy characterization and the heat storage performance test. The activation energy for the thermochemical reaction process notably decreased after the addition of Ni-CNTs possibly because Ni-CNTs provide efficient hydrophilic reaction interface and exhibit surface effect in the hydration reaction. Among these TCMs, Ni-CNTs- $\mathrm{LiOH} \cdot \mathrm{H}_{2} \mathrm{O}-1$ showed the lowest activation energy $\left(23.3 \mathrm{~kJ} \mathrm{~mol}^{-1}\right)$, highest thermal conductivity $\left(3.78 \mathrm{~W} \mathrm{~m}^{-1} \mathrm{~K}^{-1}\right)$, and highest heat storage density (3935 $\mathrm{kJ} \mathrm{kg}^{-1}$ ), which is 5.9 times higher than pure lithium hydroxide after the same hydration duration. The heat storage density and the thermal conductivity of Ni-CNTs$\mathrm{LiOH} \cdot \mathrm{H}_{2} \mathrm{O}$ are great higher than 1D MWCNTs and 2D graphene oxide modified $\mathrm{LiOH} \cdot \mathrm{H}_{2} \mathrm{O}$. The selection of $3 \mathrm{D}$ carbon nanoadditives as composed part of the chemical heat storage materials is a very efficient way to enhance comprehensive performance of heat storage activity component.

\section{Conflicts of interest}

There are no conflicts to declare.

\section{Acknowledgements}

This work was supported by Science and Technology Planning Project of Guangdong Province, China (2016A050502040), Research project of the Chinese Academy of Sciences (QYZDYSSW-JSC038) and the National Natural Science Foundation of China (No. 51406209).

\section{References}

1 A. Gil, M. Medrano, I. Martorell, A. Lázaro, P. Dolado, B. Zalba and L. F. Cabeza, State of the art on high temperature thermal energy storage for power generation. Part 1-concepts, materials and modellization, Renewable Sustainable Energy Rev., 2010, 14, 31-55.

2 Q. Q. Tang, J. Sun, S. M. Yu and G. C. Wang, Improving thermal conductivity and decreasing supercooling of paraffin phase change materials by n-octadecylaminefunctionalized multi-walled carbon nanotubes, RSC $A d v$., 2014, 4, 36584-36590.

3 V. A. Salomoni, C. E. Majorana, G. M. Giannuzzi, A. Miliozzi, R. D. Maggio, F. Girardi, D. Mele and M. Lucentini, Thermal storage of sensible heat using concrete modules in solar power plants, Sol. Energy, 2014, 103, 303-315.

4 L. Miró, M. E. Navarro, P. Suresh, A. Gil, A. I. Fernández and L. F. Cabeza, Experimental characterization of a solid industrial by-product as material for high temperature sensible thermal energy storage (TES), Appl. Energy, 2014, 113, 1261-1268.

5 Z. Y. Lu, D. S. Hou, B. W. Xu and Z. J. Li, Preparation and characterization of an expanded perlite/paraffin/graphene oxide composite with enhanced thermal conductivity and leakage-bearing properties, $R S C A d v ., 2015$, 5, 107514107521.
6 A. Kardam, S. S. Narayanan, N. Bhardwaj, D. Madhwal, P. Shukla, A. Verma and V. K. Jain, Ultrafast thermal charging of inorganic nano-phase change material composites for solar thermal energy storage, RSC Adv., 2015, 5, 56541-56548.

7 A. Shkatulov and Y. Aristov, Calcium hydroxide doped by $\mathrm{KNO}_{3}$ as a promising candidate for thermochemical storage of solar heat, RSC Adv., 2017, 7, 42929-42939.

8 M. Rothensteiner, A. Bonk, U. F. Vogt, H. Emeriche and J. A. V. Bokhoven, Structural changes in equimolar ceriahafnia materials under solar thermochemical looping conditions: cation ordering, formation and stability of the pyrochlore structure, RSC Adv., 2017, 7, 53797-53809.

9 T. Yan, R. Z. Wang, T. X. Li, L. W. Wang and I. T. Fred, A review of promising candidate reactions for chemical heat storage, Renewable Sustainable Energy Rev., 2015, 43, 13-31.

10 P. Pardo, A. Deydier, Z. Anxionnaz-Minvielle, S. Rougé, M. Cabassud and P. Cognet, A review on high temperature thermochemical heat energy storage, Renewable Sustainable Energy Rev., 2014, 32, 591-610.

11 H. Ishitobi, K. Uruma, M. Takeuchi, J. Ryu and Y. Kato, Dehydration and hydration behavior of metal-salt-modified materials for chemical heat pumps, Appl. Therm. Eng., 2013, 50, 1639-1644.

$12 \mathrm{H}$. Ogura, T. Yamamoto and H. Kage, Efficiencies of $\mathrm{CaO} /$ $\mathrm{H}_{2} \mathrm{O} / \mathrm{Ca}(\mathrm{OH})_{2}$ chemical heat pump for heat storing and heating/cooling, Energy, 2003, 28, 1479-1493.

13 D. A. Sheppard, M. Paskevicius and C. E. Buckley, Thermodynamics of hydrogen desorption from $\mathrm{NaMgH}_{3}$ and its application as a solar heat storage medium, Chem. Mater., 2011, 23, 4298-4300.

14 K. Kyaw, T. Shibata, F. Watanabe, H. Matsuda and M. Hasatani, Applicability of zeolite for $\mathrm{CO}_{2}$ storage in a $\mathrm{CaO}-\mathrm{CO}_{2}$ high temperature energy storage system, Energy Convers. Manage., 1997, 38, 1025-1033.

15 X. X. Yang, H. Y. Huang, Z. H. Wang, M. Kubota, Z. H. He and N. Kobayashi, Facile synthesis of graphene oxide-modified lithium hydroxide for low-temperature chemical heat storage, Chem. Phys. Lett., 2016, 644, 31-34.

16 W. Wongsuwan, S. Kumar, P. Neveu and F. Meunier, A review of chemical heat pump technology and applications, Appl. Therm. Eng., 2001, 21, 1489-1519.

17 M. Kubota, N. Horie, H. Togari and H. Matsuda, Improvement of hydration rate of $\mathrm{LiOH} / \mathrm{LiOH} \cdot \mathrm{H}_{2} \mathrm{O}$ reaction for low-temperature thermal energy storage, Annual Meeting of Japan Society of Refrigerating and Air Conditioning Engineers, Tokai University, Japan, 2013.

18 G. Whiting, D. Grondin, S. Bennici and A. Auroux, Heats of water sorption studies on zeolite- $\mathrm{MgSO}_{4}$ composites as potential thermochemical heat storage materials, Sol. Energy Mater. Sol. Cells, 2013, 112, 112-119.

19 S. Hongois, F. Kuznik, P. Stevens and J. J. Roux, Development and characterisation of a new $\mathrm{MgSO}_{4}$-zeolite composite for long-term thermal energy storage, Sol. Energy Mater. Sol. Cells, 2011, 95, 1831-1837.

20 Z. P. Zeng, X. C. Gui, Z. Q. Lin, L. H. Zhang, J. Yi, A. Y. Cao, Y. Zhu, R. Xiang, T. Z. Wu and Z. K. Tang, Carbon nanotube 
sponge-array tandem composites with extended energy absorption range, Adv. Mater., 2013, 25, 1185-1191.

21 K. Zhang, T. T. Li, L. Ling, H. F. Lu, L. Tang, C. W. Li, L. J. Wang and Y. G. Yao, Facile synthesis of high density carbon nanotube array by a deposition-growthdensification process, Carbon, 2017, 114, 435-440.

22 E. Muñoz-Sandoval, A. J. Cortes-Lopez, B. Flores-Gomez, J. L. Fajardo-Díaz, R. Sanchez-Salas and F. Lopez-Urías, Carbon sponge-type nanostructures based on coaxial nitrogen-doped multiwalled carbon nanotubes grown by CVD using benzylamine as precursor, Carbon, 2017, 115, 409-421.

23 J. K. Chen, X. C. Gui, Z. Q. Lin, Z. K. Tang, M. M. Lee, A. Wokaun and T. Lippert, Pulsed ultra-violet laser interactions with ultra-low-density porous carbon nanotube sponges, Carbon, 2015, 93, 604-610.

24 X. Su, J. Wu and B. J. Hinds, Catalytic activity of ultrathin Pt films on aligned carbon nanotube arrays, Carbon, 2011, 49(4), 1145-1150.

25 Y. Shen, D. Sun, L. Yu, W. Zhang, Y. Y. Shang, H. R. Tang, J. F. Wu, A. Y. Cao and Y. H. Huang, A high-capacity lithium-air battery with Pd modified carbon nanotube sponge cathode working in regular air, Carbon, 2013, 62, 288-295.

26 Q. Cao, S. J. Han, G. S. Tulevski, Y. Zhu, D. D. Lu and W. Haensch, Arrays of single-walled carbon nanotubes with full surface coverage for high-performance electronics, Nat. Nanotechnol., 2013, 8, 180-186.

27 L. M. Zhang, X. L. Sui, L. Zhao, G. S. Huang, D. M. Gu and Z. B. Wang, Three-dimensional hybrid aerogels built from graphene and polypyrrole-derived nitrogen-doped carbon nanotubes as a high-efficiency Pt-based catalyst support, Carbon, 2017, 121, 518-526.

28 B. W. Xu and Z. J. Li, Paraffin/diatomite/multi-wall carbon nanotubes composite phase change material tailor-made for thermal energy storage cement-based composites, Energy, 2014, 72, 371-380.

29 W. D. Liang, Y. Wu, H. X. Sun, Z. Q. Zhu, P. S. Chen, B. P. Yang and A. Li, Halloysite clay nanotubes based phase change material composites with excellent thermal stability for energy saving and storage, RSC Adv., 2016, 6, 19669-19675.

30 Z. P. Liu, R. Q. Zou, Z. Q. Lin, X. C. Gui, R. J. Chen, J. H. Lin, Y. Y. Shang and A. Y. Cao, Tailoring carbon nanotube density for modulating electro-to-heat conversion in phase change composites, Nano Lett., 2013, 13(9), 4028-4035.

31 X. X. Yang, S. J. Li, H. Y. Huang, J. Li, N. Kobayashi and M. Kubota, Effect of carbon nanoadditives on lithium hydroxide monohydrate-based composite materials for low temperature chemical heat storage, Energies, 2017, 10(5), 644-653.

32 S. J. Li, H. Y. Huang, X. X. Yang, C. G. Wang, N. Kobayashi and M. Kubota, A facile method to construct graphene oxide-based magnesium hydroxide for chemical heat storage, Nanoscale Microscale Thermophys. Eng., 2017, 21(1), $1-7$.
33 S. J. Li, H. Y. Huang, X. X. Yang, Y. Bai, J. Li, N. Kobayashi and M. Kubota, Hydrophilic substance assisted low temperature $\mathrm{LiOH} \cdot \mathrm{H}_{2} \mathrm{O}$ based composite thermochemical materials for thermal energy storage, Appl. Therm. Eng., 2018, 128, 706-711.

34 O. Myagmarjav, J. Ryu and Y. Kato, Lithium bromidemediated reaction performance enhancement of a chemical heat-storage material for magnesium oxide/ water chemical heat pumps, Appl. Therm. Eng., 2014, 63, 170-176.

35 J. K. Chinthaginjala, D. B. Thakur, K. Seshan and L. Lefferts, How carbon-nano-fibers attach to Ni foam, Carbon, 2008, 46, 1638-1647.

36 M. Kubota, S. Matsumoto, H. Matsuda, H. Y. Huang, Z. H He and X. X. Yang, Chemical heat storage with $\mathrm{LiOH} / \mathrm{LiOH} \cdot \mathrm{H}_{2} \mathrm{O}$ reaction for low-temperature heat below $373 \mathrm{~K}$, Adv. Mater. Res., 2014, 953-954, 757-760.

37 D. S. Yuan, J. X. Chen, J. H. Zeng and S. X. Tan, Preparation of monodisperse carbon nanospheres for electrochemical capacitors, Electrochem. Commun., 2008, 10, 1067-1070.

38 M. Mehrali, L. S. Tahan, M. Mehrali, T. M. I. Mahlia and H. S. Cornelis Metselaar, Effect of carbon nanospheres on shape stabilization and thermal behavior of phase change materials for thermal energy storage, Energy Convers. Manage., 2014, 88, 206-213.

39 X. C. Liu, Y. Osaka, H. Y. Huang, H. Huhetaoli, J. Li, X. X. Yang, S. J. Li and N. Kobayashi, Development of lowtemperature desulfurization performance of a $\mathrm{MnO}_{2} / \mathrm{AC}$ composite for a combined $\mathrm{SO}_{2}$ trap for diesel exhaust, $R S C$ $A d v .$, 2016, 6, 96367-96375.

40 J. F. Wang, H. Q. Xie, Z. Xin, Y. Li and L. F. Chen, Enhancing thermal conductivity of palmitic acid based phase change materials with carbon nanotubes as fillers, Sol. Energy, 2010, 84, 339-344.

41 G. Q. Zhang, Z. Li, H. Y. Zheng, T. J. Fu, Y. B. Ju and Y. C. Wang, Influence of the surface oxygenated groups of activated carbon on preparation of a nano $\mathrm{Cu} / \mathrm{AC}$ catalyst and heterogeneous catalysis in the oxidative carbonylation of methanol, Appl. Catal., B, 2015, 179, 95-105.

42 B. X. Wang, L. P. Zhou and X. F. Peng, Surface and size effects on the specific heat capacity of nanoparticles, Int. J. Thermophys., 2005, 27, 139-151.

43 L. J. Chen, R. Q. Zou, W. Xia, Z. P. Liu, Y. Y. Shang, J. L. Zhu, Y. X. Wang, J. H. Lin, D. G. Xia and A. Y. Cao, Electro-and photodriven phase change composites based on waxinfiltrated carbon nanotube sponges, ACS Nano, 2012, 6, 10884-10892.

44 T. Szabo, O. Berkesi, P. Forgo, K. Josepovits, Y. Sanakis, D. Petridis and I. Dekany, Evolution of surface functional groups in a series of progressively oxidized graphite oxides, Chem. Mater., 2006, 18, 2740-2749.

45 S. F. Weng and Y. Z. Xu, Fourier transform infrared spectrum analysis, Chemical Industry Press of China, 2016.

46 L. Zhao, X. Y. Li, C. Hao and C. L. Raston, $\mathrm{SO}_{2}$ adsorption and transformation on calcined $\mathrm{NiAl}$ hydrotalcite-like compounds surfaces: an in situ FTIR and DFT study, Appl. Catal., B, 2012, 117-118, 339-345. 
47 K. Hoang, A. Janotti and C. G. Van de Walle, The particle-size dependence of the activation energy for decomposition of lithium amide, Angew. Chem., 2011, 123, 10352-10355.

48 Z. X. Cui, Y. Q. Xue, L. B. Xiao and T. T. Wang, Effect of particle size on activation energy for thermal decomposition of nano-CaCO 3, J. Comput. Theor. Nanosci., 2013, 10, 569-572.

49 Z. Y. Li, K. Yu, J. Liu, Y. W. Tian and Y. C. Zhai, Effect of diameter on apparent activation energy of non-isothermal decomposition reaction of nano- $\mathrm{Mg}(\mathrm{OH})_{2}$ powder, Curr. Nanosci., 2012, 8, 97-101. 